\title{
3: 41216004-41256938
}

National Cancer Institute

\section{Source}

National Cancer Institute. 3: 41216004-41256938. NCI Thesaurus. Code C42019.

Physical location of CTNNB1_Gene 